\title{
Space and Culture
}

http://sac.sagepub.com/

\section{Industrial and Human Ruins of Postcommunist Europe} Anca Pusca

Space and Culture 2010 13: 239 originally published online 28 April 2010

DOI: $10.1177 / 1206331210365255$

The online version of this article can be found at:

http://sac.sagepub.com/content/13/3/239

\section{Published by: (SAGE}

http://www.sagepublications.com

Additional services and information for Space and Culture can be found at:

Email Alerts: http://sac.sagepub.com/cgi/alerts

Subscriptions: http://sac.sagepub.com/subscriptions

Reprints: http://www.sagepub.com/journalsReprints.nav

Permissions: http://www.sagepub.com/journalsPermissions.nav

Citations: http://sac.sagepub.com/content/13/3/239.refs.html 


\title{
Industrial and Human Ruins of Postcommunist Europe
}

\author{
Anca Pusca'
}

\begin{abstract}
With the former industrial cities of Eastern Europe in ruin — once the pillars of these economiesthe attention of both investors and academics has shifted toward capital cities and their new political and economic potential fueled by the rise of new governments and new foreign direct investment. The failed attempts to privatize many of these former industrial spaces has left entire cities in ruin and despair, forgotten by all but artists and preservationists, who see these spaces not only as aesthetically inspiring but also as charged with redemptive potential. This article puts forward an alternative exploration of the Eastern European postcommunist transition through these ruined spaces, arguing that the aesthetic dimension of change is key to understanding the human impact of the transition. Focusing on two former industrial sites-the Hunedoara Ironworks in Romania and the Vitkovice Ironworks in the Czech Republic - the article seeks to understand the rhetorical and material relationship between these ruined spaces and the workers who once inhabited them as well as the effect that different practices of representation-mainly photography-and preservation have had on these spaces.
\end{abstract}

\section{Keywords}

postcommunism, industrial ruins, aesthetics, Romania, Czech Republic

\section{Introduction}

Perhaps the sorest sight for the traveler through the Eastern European countryside is that of industrial ruins, surrounded by cities and communities that now lie in equal ruination. Yet this sight need not always be sore, for abandoned ruins in particular, even industrial ones, have long served as inspiration for artists, writers, and performers who saw in them not only great aesthetic but also redemptive potential for those who still lived within these ruins. Bringing back the human element that is always connected to the otherwise purely material construction, these artistic efforts of representation ${ }^{1}$ and preservation serve as important explorations of the emotional, rhetorical, and human investment in buildings such as industrial complexes that once

'Goldsmiths, University of London, London, UK

Corresponding Author:

Anca Pusca, Goldsmiths, University of London, Department of Politics, Warmington Tower,

Office 604, New Cross, London SEI4 6NW, UK

Email: a.pusca@gold.ac.uk 
were at the heart of entire communities. Using the Hunedoara and Vitkovice ironworks as material metaphors of transitions and change, this article seeks to provide a different take on the eastern European postcommunist transitions: one that privileges the aesthetic and human dimension of change over the economic and institutional one. The article thus serves a double purpose: first and foremost, to provide an original exploration of transition and change through an analysis of industrial ruins and aesthetization practices connected to them, and second, to suggest the possibility of such alternative approaches to students and scholars of postcommunist transitions.

Industrial ruins are certainly not your usual entry point into the study of postcommunist transitions. The closest attempts to theorize them in this context have generally come out of the privatization literature that saw these ruins as a direct result of failing economic practices or ingrained corruption (Iatridis \& Gary Hopps, 1998; Kirk, 2003; Thirkell, Petkov, \& Vickerstaff, 1998), as well as, to a lesser extent, the democratization literature that explored industrial sites as the birth place of the revolutionary ethos (Dahrendorf, 1997; Havel, 1992; Kaldor \& Vejvoda, 1999; Tismaneanu, 1991). Outside of the Eastern European transitions and democratization literature, industrial ruins are studied mainly in the urban and cultural studies, political geography, and architectural design literature, where emphasis is often more abstractly placed on construction and destruction practices fueled by particular understandings of the role of place, space, and the city (Boyer, 1988; Graham, 2003; Hayden, 1997). Although there have certainly been attempts to bring in theories of space, place, cities, and everyday life into political theory and more importantly Eastern European studies (Boym, 2001; Buck-Morss, 2000; Heller, 1970), these remain to a large extent marginal. The more recent Aesthetic Turn in International Relations (Bleiker, 2001; Der Derian, 2001; Shapiro, 2006; Weber, 2006) promises to open new avenues for such analyses, although the turn has for the most part been focused on representation practices of war within the West, with a few notable exceptions (Bleiker, 2007; Moore, 2006).

Despite this poor academic record, at least in the particular context of Eastern Europe, the fascination with (industrial) ruins dates back to Eugene Atget, Andrieu and the photographers of the Franco-Prussian war and the Paris Commune (Luxenberg, 1998), Georg Simmel (Simmel, 1959), and Walter Benjamin (Benjamin, 1982). They have inspired contemporary writers such as Tim Edensor (2005b) to consider the relationship between materiality and human emotionality in the context on industrial ruins, which, as he argues, are particularly imbued with ghosts, memories, and spatial practices of resistance that serve not only as a reminder of the damaging effects of change but also of the continuing capacity of these spaces to challenge the spatial and emotional forms of organization that have followed them.

Industrial ruins in Eastern Europe are seen to represent, perhaps more so than anything else, the hard shell of communism: the last remains of a now past era that are littered around the postcommunist landscapes, often empty and abandoned, stripped of any recyclable material to a point where their previous role becomes unrecognizable even to those who used to work there. Attempts to revive these sites through privatization have more often than not failed; the success stories having only been able to salvage a very small part of the industrial plants that once stood there. As the debate around these former industrial sites is moving ahead with the recognition that many of them are not salvageable and will remain nothing but empty and decaying shells, attempts to aestheticize and museumize them are opening up new ways of engaging with these spaces by taping into their emotional and redemptive potential: their ability to provide both hope and a new sense of purpose to the communities that surround them. Decay need thus not always symbolize the death of a particular utopia but also the breeding ground of new hopes and utopias. 


\section{Space, Utopia, and Dystopia}

Space, and the built environment in general, has always been connected to certain notions of human utopia, whether social, economical, or political (Buck-Morss, 1995; Sennett, 1994). Decayed spaces such as industrial ruins can thus, by correspondence, be connected to a certain notion of dystopia. If, as Susan Buck-Morss eloquently explains, spaces and buildings were used to visually inscribe the communist utopia into people's minds, the ruination of these same spaces can be directly connected to the dismantling of that utopia. Along with the buildings, it was not just an ideology - mass utopia or dreamworld as Buck-Morss calls it - that went crumbling, but also a particular collective and individual identity, a social order that sustained life both physicallythrough the industrial platforms and the cities surrounding them - as well as emotionally - through the communities and solidarity that emerged within them.

This collapse has often been examined under the concept of disillusionment - understood as the loss and destruction of particular collective illusions ${ }^{2}$ - a concept however that has been rarely connected and explored through the prism of space and spatial destruction. Academics were quick to investigate postcommunist disillusionment through interviews and polling techniques and attempt to theorize it in light of notions of social disruption and economic need, yet most ignored its spatial representations in postcommunist cities: the sudden (physical) collapse of all industries; the destruction of local government buildings, monuments, and stores; and the emergence of so-called temporary architectures - open markets, make-shift bars, and kiosks - that resembled partial ruins more than construction.

Dystopia — and the collective disillusionment that went along with it—was clearly marked in the physical collapse of cities, especially industrial cities, whose infrastructure relied almost exclusively on the industries that created them in the first place. Thus, heating, water, gas, and electricity distribution began to collapse, resulting not only in further infrastructure decay but also in a continuous decay of the bodies inhabiting the cities. Accidents such as gas explosions-as a result of replacing water heating with gas heating using make-shift secondhand boilers-became more and more common in industrial cities throughout Romania, whereas suicide rates in industrial towns skyrocketed along with unemployment (World Health Organization, 2006).

The ruination of the human body — both physical and psychological — went hand in hand with the ruination of space. As industrial spaces were slowly emptied out - through the theft of all recyclable materials - so were the industrial cities connected to them: this was marked by mass migration toward other cities and sometimes the countryside - which provided at least a means of subsistence through agriculture - as well as migration toward Western Europe - rings of trafficking as well as illegal workers can often be traced back directly to such failed industrial towns (B. Iancu, 2006; C. Iancu, 2007; S. Iancu, 2007; Ioan, 2006). The rate of decay was quick: within 2 or 3 years industrial horizons became unrecognizable, collapsed in a pool of dust, regrets, corruption, and, more important, a sense of self-destruction and futility that directly challenged discourses of progress and positive change.

Just like the utopia of communist industries was built both on the physical space itself as well as on a certain discourse of worker emancipation, the dystopia emerged not only through the physical destruction of these space but also through the replacement of their symbolism: the revolutionary symbolism, imbued both by communist propaganda as well as the 1989 revolutions - the majority of which originated on industrial platforms - was quickly replaced with a symbolism of disruption and threat - as industrial cities collapsed and workers rebelled, often disrupting the fragile order of the years immediately following 1989. Ruined industrial spaces thus became a testimony of change, as well as a testimony of the human ruination that followed. 
Yet many of these ruins lay, often conveniently, outside of major capital cities and could thus be easily disregarded as nonrepresentative of the general experience of the postcommunist transition: They were the "minority" losers of the transition, while everybody else stood to win. This kind of discourse erased not only the agonizing pain of millions of people but also the extent to which postcommunist change was at least equally founded on destruction and ruins as it was on construction and images of positive change. The erasure of ruins, both physically as well as metaphorically, denied former workers the possibility of positive engagements with their former work spaces and the rest of the population the ability to identify with their plight.

\section{Spaces and Bodies}

As Richard Sennett argues in Flesh and Stone (1994), the body and the built environment have always lived in close symbiosis throughout history, with notions and understandings and space and construction often being directly derived from knowledge of the body, organs, and blood circulation. The traditional, Roman city, according to Sennett, was designed to function very much like the body: with a center that pumped "blood" into the city and peripheries that served to feed the center. Community life was created through particular designs of the city that brought individuals together in central squares during the day and dispersed them in individual and family accommodations during the night. If the central squares, the heart of the traditional city, generally housed churches and parliaments, modern cities and communist industrial cities in particular, replaced these with industrial platforms: the latter becoming the productive heart of the city, the place where the community gathered under the watchful eye of the state.

Like most modern cities, communist industrial cities were often artificially created from scratch: people and construction and production materials were uprooted and brought in from different parts of the country, appeased by the promise of an urban lifestyle - family flats, cinemas, schools, medical centers - and the security of a stable job for each member of the family. Although artificially created, the sense of collectivity developed in such cities was not easily replicated in nonindustrial cities - trained together, living and working together in traits and jobs that rarely rotated, inhabitants of industrial cities learned to depend on each other, both on the line of production as well as outside. Their bodies inhabited the industrial spaces in a mutual symbiosis that extended much beyond the workplace itself, toward the entire city. The city was the workers and the workers were the city. This symbiosis was certainly not unique to communist industrial cities. Industrial cities in the West experienced a similar collective ethos, as John Kirk explains was the case in the United Kingdom, "the working community is not merely a material reality but a collectivist imaginary, in which the sense of purpose and endeavor is a shared one" (Kirk, 2003, p. 180). Unlike the West though, the collective imaginary of the communist industrial city was carefully designed and controlled by the state, and thus in many ways dependent on the continuing existence of the state.

With the collapse of the communist state and the process of centralized economics, it was not just the economy that unraveled but also this collective imaginary that depended on an ingrained respect for the worker as a human being and a social category, as well as for his work. The workers and the physical space they inhabited - the industrial platform - formed the belly button (umbilicus) of the communist industrial city. The destruction of the umbilicus meant the destruction of the city, for with the umbilicus lay the purpose and logic of the city. As Sennett argues was the case with historical cities, a city could only be rebuilt from the old umbilicus outward, often requiring either the reconstruction of the "temple" - in this case the industrial platform — or at 
least the symbolic recognition of the old temple - either through a religious symbol or a square. If the logic still applies, then the reconstruction and revival of communist industrial cities also depends on the ability to physically and materially acknowledge the former industrial platform as the center, either through preservation and restoration/muzeumization efforts or through representation practices that serve to memorialize the workers, their community, and the spaces they once inhabited.

Each of these practices serves to recreate the illusion of a particular space and interaction that is now missed: either by preserving actual parts of the former space, by recreating similar spaces, or by symbolically enacting a particular memory. They are key to proving not only an important sense of belonging to a community but also of self-worth. With many postcommunist industrial towns often capitalizing - usually rhetorically_on their former "glory" as a means of attracting new investments, tourism, and state or regional funding — such as, more recently, EU fundingmemory clearly plays an important role in their self-image and future image. Whereas historical industrial cities such as Gdansk (Tolle, 2008) are taking the lead in such practices - playing the card of "Solidarity and Freedom" to secure EU funding - others are following in its tracks. Success, however, is often determined by the opportunities for regeneration: as a port, Gdansk can easily survive on its beauty alone. Other industrial cities such as Hunedoara and Vitkovice are left playing a less successful card: with declining populations and significant infrastructural challenges, they are not ideal candidates for the kind of regeneration projects that rely heavily on memorialization and preservation. The decay is such cities is thus, for the most part, likely to continue to a point of complete destruction, leaving just enough room for photographers to capture the ruins before their complete erasure.

\section{Representation Practices: The Gaze and the Ruin}

The closure of former industrial plants pushed not only workers but entire communities permanently outside of these spaces, denying them the physical and emotional comfort of coming into contact with them again. Within a matter of months, after the collapse of the industry sector in 1990, factories closed their gates, built new fences, or simply started tearing through old structures looking for scrap to resell. The workers and local communities could only look in from outside as their former offices, workspaces, and assembly lines were torn apart, leaving behind complete destruction and desolation. Machinery they once serviced lay abandoned, taken apart or rusting in the rain, a constant reminder to the futility of years of service and hope for potential reinvestments. Forced to look in from outside, the worker became seer: the gaze and not the body leading the interaction with space. In this shift, memory and reflection replaces action, leading to melancholy and a certain amount of disengagement. As Walter Benjamin (1970) explains, the panoramic gaze imposes both a physical as well as a mental and emotional distance that forces the mind to reflect on the "object" in sight.

The process of reflection is particularly powerful at the point of extinction, as Graeme Gilloch (1997) explains,

The posthumous existence of the object is the period of judgement which negates the original intention and meaning of the artefact. The "truth content" of the object is revealed at the moment of its extinction. Ruination, the fracturing of the deceptive surface of the object, frees the critical, utopian moments buried within it. (p. 110)

The ruination of these industrial complexes frees them of the utopian communist rhetoric embedded in them, but with it, it also burdens them with new questions about the possibility 
of creating nonutopian spaces/reflections/representations that do however still capture the pride, self-worth, and sacrifice of the worker in history. If Benjamin (1963/1998, p. 177) is correct in arguing that "in the ruin history has physically merged into the setting," then erasing the ruin is equivalent to the erasure of irrecoverable history. The physicality/materiality of the ruin is thus essential to the possibility of reflection. Practices of representation, such as photography, according to Benjamin, serve only as a second best mediator, an illusionary pause in the destruction process.

Philosophers such as Jacque Ranciere, however, revived the potential of these (aesthetic) practices by arguing that it lies precisely in their unrivaled ability to trick the eye outside of its routine, pointing to new and unexpected angles, subjects, and planes. He nicely captures this in his definition of aesthetic experience as "a specific sphere of experience which invalidates the ordinary hierarchies incorporated in everyday sensory experience" (Ranciere, 2005, p. 15). For him, aesthetic experiences are not dominated by the realm of the "artistic" but rather the realm of the "everyday." The gazes are "everyday" gazes of "everyday" people who choose to break with routines and pursue objectives that challenge previously established hierarchies: in his case, workers in 17th-century France breaking the hierarchy of time and knowledge by pursuing intellectual inclinations at night - the time designated for sleep, as far as workers are concerned (Ranciere, 1981/1989).

As the gaze of Ranciere's workers shifts from machinery to the written text, so does their position of subordination through the imagination of new possibilities. The workers reimagine themselves through a simple shift of the gaze. The "shock" of discovering new possibilities is not the "coup de foudre" of the Kantian "sublime" but rather the slow shifting of routines that eventually lead to an attempt to clearly redefine their positioning - in Ranciere's analysis, the French Revolution. The aesthetics of change for Ranciere is thus not contemplative alone but rather active, carrying a powerful potential in itself. Aesthetics — often viewed as representation - is not separated from action. New forms of seeing create new possibilities for action, as Ranciere explains.

The redemptive character of the aesthetics of change, as pointed out by Ranciere, is however challenged by the privileging of the gaze of "outsiders." Aestheticizing practices such as photography, film, and museumization, aimed at the industrial ruins of postcommunist Europe, have mainly been led by "outsiders," people whose gaze is not part of the "everyday" of the communities involved. With workers often lying outside of the picture-literally speaking, the photographs depicting industrial ruins - it is easy to decouple the scenery from a particular historical context and admire it for its physical/geometrical lines alone. The human traces serve only as temporary reminders of a population that must have been there sometime. The worker disappears physically, as a material fragment, and the image of the world no longer contains him/her: as such, the worker disappears as an ideational category.

Although some artists and photographers purposefully attempt to bring the worker back into the scenery, they often blend them into the space itself, creating the visual illusion of the human and the ruin physically merged into one: the specter of colors swallows the workers into the form of the whole, their matter seemingly no longer organic, alive, causing them to become just a material fragment, just like the tools that they hold or the chair on which they sit. Vaclav Jirasek's portraits of workers nicely capture the merging of the two: a beautiful metaphor of symbiotic ruination, material, and physical decay into one. The possibility of salvation is literally out of the "picture" as the tired or covered eyes of the workers reveal complete passivity and acceptance of their ruined "fate." Despite its destruction, the space around them remains comfortable for as long as they can inhabit it. The moment of spatial exclusion is the moment of death. 

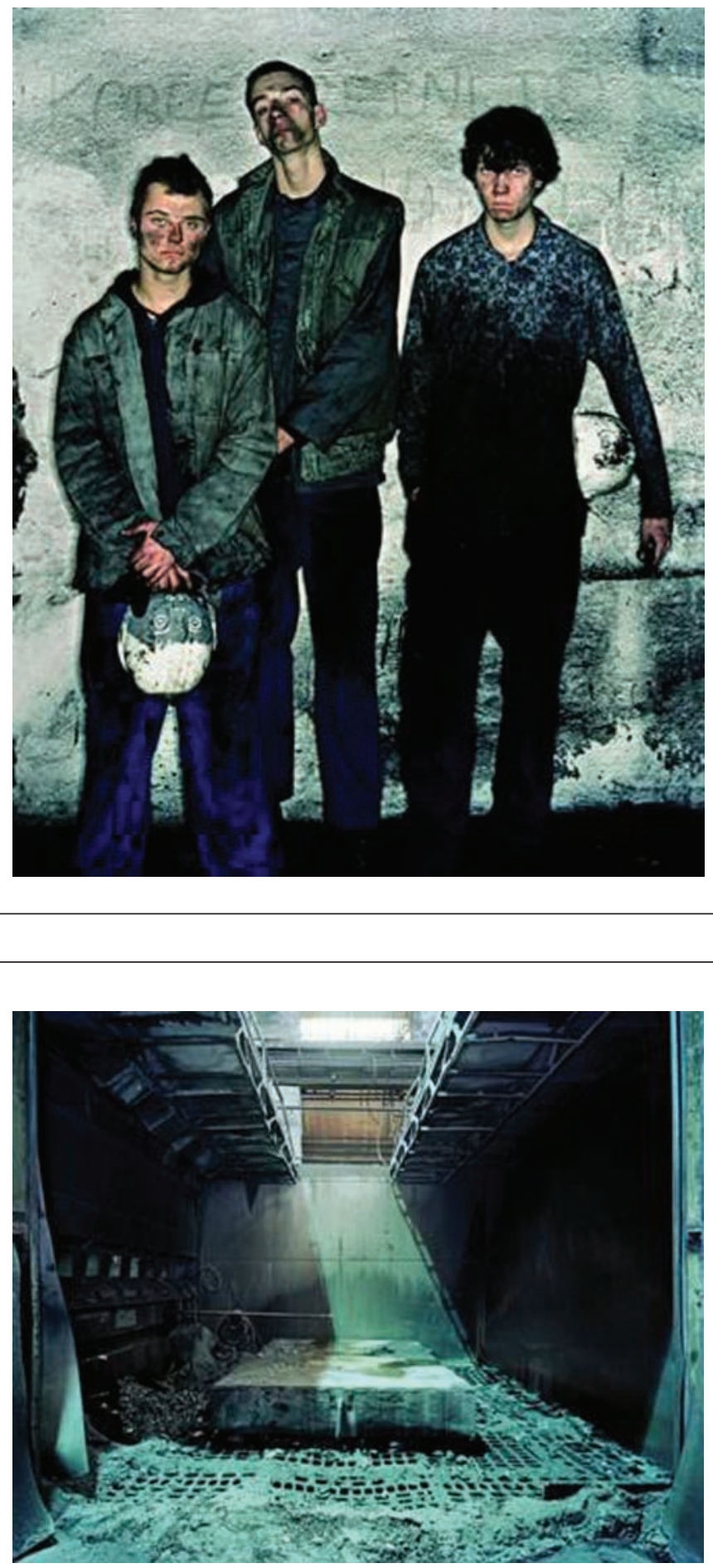
Photographic representations of ruins and the workers inhabiting them also carry the potential of creating reflective counter-sites, by symbolically emptying space out of its former utility and human content and refilling it with new meaning. Foucault captures this process through his notion of heterotopias: defined as "counter-sites, a kind of effectively enacted utopia in which the real sites ... are simultaneously represented, contested and inverted" (Foucault, 1967). These reflective counter-sites can however be as shallow or deep as the artist chooses to make them. In fact, much of industrial photography is about capturing design, playing with light and angles, and glorifying ruins for their natural texture. Often taken in black and white to accentuate shadows and lines, this kind of photography acts more as a reflection on the skill of the photographer as opposed to the subject itself: the ruin is only there as a frame and not as a meaningful subject. Although the creatively meaningful possibilities are there, they need not always be explored to their full positive potential.

Assigning a particular mood to the past through practices of representation such as photography and museumization does put us, in a way, in control of history, as Schonle (2006) and Lahusen (2006) argue, and any such form of control is potentially dangerous. It is only through the unmediated gaze alone, they argue, that the natural, organic decay can be captured. Any attempts to aestheticize it through the eyes of the artist, photographer, or preservationist ruins its reflective potential: "only the not-yet aestheticized refuse of . . . modernity, the post-industrial wasteland, can offer a genuine alterity to mass culture and thus provide a heterotopia that can inspire alternative identities and forms of sociability" (Schonle, 2006, p. 654). It is interesting however that the industrial wasteland would serve as an ideal of identity and sociability to be contrasted with the, presumably negative, current "mass culture." Tim Edensor (2005b) seems to also support this view, arguing that they provide an illuminating contrast to the "order" assigned to space and practices in the city.

Yet the industrial ruins of postcommunist Europe are most often sealed off, erased form the gaze of outsiders and allowing only limited peaks for the gaze of local communities. The grief and pain associated with the ruination of these sites is not only triggered by their decay but also by the inability to interact with them. Aestheticizing practices such as photography or museumization, from this perspective, do not necessarily appear as negative. Although they run the risk of feeding the already rampant communist nostalgia, as Lahusen suggests, he also nicely points out that this is unlikely to happen to "those who still live in its ruins, because they are home" (Lahusen, 2006, p. 736). One can however only assess the positive versus negative effects of different representation practices, such as photography and museumization, in context alone. For this purpose, the remainder of the article will focus on a closer examination of some of the representation practices surrounding the Hunedoara Ironworks - the photography of the Igloo Photographers in Kombinat - and the Vitkovice Ironworks - the photography of Vaclav Jirasek and the museuminzation led by Milos Matej.

\section{Photographing the Hunedoara Ironworks}

The steel and metal processing plant at Hunedoara - also known as the Fire Fortress - employed more than 20,000 workers as of the late 1980 s and sprawled over 250,000 square meters, not including the funicular and rail connections to exploratory sites or the water dam that redirected water for the cooling process. The gigantesque stature was supported by hundreds of constructions on site, from four blast furnaces to several cooling towers, to tens of industrial halls, private rail system and locomotives, roads, and over-the-surface piping. Built originally in 1881 on a historical metal extraction and processing site that goes back to Roman times, the Hunedoara processing plant continued to grow both in size and production capacity until 1990, when the collapse of the communist systems throughout Central and Eastern Europe brought much of the production process 
to a halt, resulting in large layoffs in 1998 - more than 7,000 people lost their job - and continuous layoffs since then as the plant fell into disarray and was sectioned and sold to different private enterprises under the privatization scheme. In 2004, there were only 3,000 workers left at the plant, now employed by Mittal Steel, one of the largest steel processing companies in the world, which acquired the Hunedoara plant as part of a larger buyout of several other metal and steel processing plants throughout the country. ${ }^{3}$

The plant lies at the heart of the city of Hunedoara - home to about 68,000 people - a grey, industrial town that once attracted people with the promise of secure jobs and now fights to support its diminishing population. With unemployment reaching a high of 17\% in 2000 (Somerii inregistrati si rata somajului, n.d.), the city managed to bounce back toward late 2005 by attracting a number of private companies through tax-free policies and the opening of an industrial park. With large parts of the former "Fire Fortress" in ruins, and most of the construction material stolen - from bricks to train tracks to knobs and anything else that could be reused - the land on which it once sat remains one of the main valuable asset of the city, apart from the two electrical furnaces that remain in use by Mittal Steel. A number of ongoing trials over property rights however keep a large part of the land unused, as different owners dispute their right over the parceled terrain - mainly a result of a faulty privatization process and corrupt mechanism of land and property registration. Despite the local administration now challenging the so-called management of theft (Staff, 2007a) that took place since the beginning of the privatization and parceling process in 1997, there is little left to be done in terms of recuperating lost property and equipment, much of which has been stolen or sold.

With Mittal Steel purchasing the plant in 2004, along with a number of other steel processing plants throughout Romania, hopes were high that further expansion and hiring would be on the way and that the former industrial circuit would be revived quickly, especially since Mittal Steel has openly expressed its ambitious plans to revive several old industries throughout Central and Eastern Europe and have invested significant amounts of money in similar plants in the Czech Republic, Poland, Ukraine, and Macedonia. These hopes dissipated rather quickly, as the new management proved to be relatively inefficient and uninterested in reviving the metallurgical industry to its full potential (Staff, 2004). With employment remaining relatively low and the profit margin unstable (Staff, 2007b), the future of the Hunedoara plant seems to be fluctuating as well.

For the majority of the workers who were laid off, the Ironworks remain nothing but a shadow of what they once were and what they stood for. The sacking forced most of the workers into early retirement or part-time jobs that keep them just at about floating level. Many have left the city or even the country in search of new opportunities. With the Ironworks unlikely to help sustain the region's economy as they once did, the city seems doomed: more than $80 \%$ of its high school students leave the city to go to university and most of them never return (C. Iancu, 2007). The infrastructure continues to decay while investment in the region remains relatively low despite the generous package of tax incentives that it offers.

The gaze of the worker thus remains focused on the increasing decay and in some cases the complete ruination of their former workplaces. In several interviews conducted by local newspapers, former workers and administrators are so saddened by the state of the Ironworks that they literally cry when walking past them or, to avoid the pain, simply refuse to lay their eyes on the site (Bimbirica, 2007). Those who have long left the city are shocked to notice on return that even the train tracks have been ripped out, leaving old wagons and locomotives stranded and emptied out. Piles of red tainted soil, used to extract iron, now have grass growing on them, adding to the desolation of the place. Although environmentally cleaner, the air of the city has already left its imprint on the graying buildings: the soot, although no longer present in the air, has melted into the materialeverything still appears dusty, although the window sills are not as dirty as they once were. 
Along with the soot, another gaze died: that of the hero worker-Stefan Tripsa. Glorified by communist propaganda as an example of hard work and efficiency, the engineer could at one point see the soot coming out of the smoke stacks of the Combinat and tell from their color and consistency which piece of machinery was malfunctioning and which needed adjusting. His naked eye could describe the quality of the iron produced without the need for laboratory results (Barb, 2007). His skills are now useless. Although he can still see the smoke stacks from his house up on a hill about 2 kilometers from the ironworks, the smoke is long gone, and long with it, his sense of purpose.

But the same desolation that is painful for workers is a source of inspiration for the photographer, in some cases even a celebration of natural originality and artful decay. For them, the emptied out spaces, the hint of the human presence, and yet the overwhelming lack thereof is appealing, intriguing, and endlessly photogenic. The pictures are ghost like, with plays of shadows and light, shocking and pleasing at the same time. With the workers gone, the spaces have a life of their own that resembles more a fairytale land, virgin territories claimed back by the forces of nature. Although they play on the element of destruction, the latter does not appear as sad but rather as aesthetically appealing. There is a creative element in these spaces, the hint of new possibilities, new beginnings. With the local communities often left out of the camera's eye, destruction can be enjoyed.

Some authors such as Miriam Cooke (2002) and Beatriz Jaguaribe (2005) argue that this so-called aesthetics of autodestruction can be quite dangerous, risking to erase specific memories of war (Cooke writes in the context of Beirut), violence (Jaguaribe writes in the context of Rio de Janeiro), and destruction by replacing them with pleasing yet "impartial images" (Cooke, 2002, p. 397). That, however, need not necessarily be the case. Although the gaze of the photographer (often a nonlocal) will always be different from, in this case, the gaze of the worker, the artistic optimism imbued in some of these pictures has the potential to breathe new life into these spaces and render them inhabitable again. Oftentimes, the photographic aesthetic of destruction is associated with an aesthetic of restoration, which, in some cases, successfully transforms otherwise hopeless communities into thriving artistic centers. ${ }^{4}$ The photograph however often seems to be a first step in larger restoration and museumization process.

As part of a larger movement that advocates the preservation of old industrial buildings as part of Romania's industrial patrimony, a group of photographers supported by Igloo press recently published a catalog of photographs focusing on industrial ruins titled Kombinat (Kombinat: Industrial Ruins of the Golden Era, 2007). The word carries particular connotations, signaling the informal way in which workers addressed the industrial plants on which they worked: Combinat. The "K" is both ironic as well as "hip," signaling a clear shift in the way in which these industrial spaces are treated. The album contains a combination of photos from the largest industrial plants within Romania - including Hunedoara — as well as a series of essays discussing the symbolism and possible future uses of these spaces. As Bruno Andresoiu explains, the album is clearly critical of communism as an ideology that had a particular impact on Romania's built environment as well as society at large:

Kombinat is not only a different way of spelling the name given to large industrial platformscombinate - but also the name that we chose to give to this bizarre world of industrial ruins, of concrete and iron monsters in decay, of forbidden sites of the now dead socialist economy. Perhaps the most somber built expression of a criminal ideology, Kombinat illustrates the violent destruction of a society in the name of ideology. Kombinat: Industrial Ruins of a Golden Era is also a collection of images from some of these industrial sites whose abandonment led not only to an advanced state of ruin of their built components but also of the society surrounding them. (Andresoiu, 2007) 
The album however goes beyond a simple critique of communism. In fact, the images speak a different language from the essays: the critique of communism is far less obvious in the pleasing black and white aesthetics of the half built and half ruined. The spaces are not mourned, saddened, or even perceived as an environmental threat. Instead, the photographs focus on unexpected symmetries and asymmetries created by the collapse and transformation of different materials, as well as on the refreshing possibility of wide-open vistas that register no human presence. The ruins appear similar to past romantic landscapes of woods, rivers, and meadows.

Although portraying the pictures as much more saddened than they really appear, the essays do however appeal to the denied optimism of the photographs, by arguing for new possible uses of the sites: generally tending toward museumizing them following the example of other past industrial cities such as London, the TATE; Manchester, the Museum of Science and Industry; or Saint-Maurice, Canada, the Forges Du Saint-Maurice (Roy \& Goulard, 1986). Proposals to preserve entire industrial or historical cities, such as downtown Detroit (Vergara, 1996) or Rhyolite, Nevada, offer even more ambitious perspectives, suggesting a possible merge of everyday spaces with museumized spaces. These proposals, although not a reality yet in the case of the Hunedoara Ironworks, would open up new possibilities for the gaze of the locals as well as that of visitors, by refilling these spaces with a different kind of human presence.

It is however important to keep in mind some of the inherent dangers of museumization. As Tim Edensor well argues, ruined industrial spaces offer much beyond pleasing aesthetics: they offer an important alternative/critique to organized public space, for they help underline the extremes of space control we experience today. Left to the whims of natural decaying elements, these spaces gain a life of their own in which human intervention is rare and often minimal, thus allowing the infrequent explorer to enter potentially reflexive spaces. Like getting into the underbelly of history, walking through ruins reveals the physical traces of time and change left as they would be after a war or an abandoned city, in which the human presence is still felt yet not physically there to rebuild and transform. Edensor seems to suggest that ruins, and perhaps industrial ruins in particular, offer what would otherwise be a once in a lifetime opportunity to explore such spaces at times other then extreme destruction - such as war or other natural disasters - for they are some of the few spaces preserved unchanged and uncontrolled in their desolate status. He explains the liberating effect of walking through such spaces almost as a unique opportunity to transpose oneself into a different time, as if one could walk into an old photograph or movie:

Ruins are sensually charged with powerful smells, profuse and intrusive textures, peculiar and delicate soundscapes, as well as perplexing visual objects, juxtapositions, and vistas, all at variance to the sensually ordered world outside. . . Movement trough the ruin confounds the performative conventions of the sites of memory identified above as well as modes of movement through the city more generally. With nobody to supervise movement, ensure assigned performative roles, or maintain peer-group norms, there is no need for self-consciousness. Released from self-policing, the body may explore the potential for expressive manoeuvres and open up to the multiple sensations present. (Edensor, 2005a, pp. 837-838)

Yet, although Edensor's arguments are well taken, it is unclear the extent to which particular museumization practices that do not interfere with the space beyond maintaining it safe would not be able to achieve similar results. The Jewelry Museum in Birmingham, for example, manages to achieve that by preserving the workshop exactly as it was left the day the workers left it for the last time. Thus, despite well-justified hesitations, the museumization of such spaces can prove to be quite successful, as we will see in the case of the Vitkovice Ironworks. The preservation of decay and destruction helps, in some cases, to normalize the otherwise radical and shocking process of 
change, through an artificial process of imposed detachment: the gaze of the museum go-er can never be the same as the gaze of a former worker visiting an abandoned site.

\section{The Three Gazes at the Vitkovice Ironworks}

Further north from the Hunedoara Ironworks lie the Vitkovice Ironworks - in what is now the Czech Republic - another large industrial platform built close to the mining area of Ostrava. With a long history, dating back to 1828 , the Ironworks helped sustain the iron-based construction of bridges, railways, boilers, and cylinders in the Austro-Hungarian Empire, later to become one of the biggest Ironworks in Europe, featuring more than six blast furnaces and a complete production line, from source to finished product. Due to the Ironworks, the region of Ostrava saw the rise of one of the largest industrial cities in the Czech Republic, the city of Ostrawa, that, just like Hunedoara, relied almost exclusively on the well functioning of the Ironworks. As early as 1944 the plant had close to 34,000 employees, with the numbers likely to have increased significantly by the late 1980s. ${ }^{5}$ Following the collapse of the communist regime in 1989, the Vitkovice Ironworks struggled along with other industries to follow the privatization strategy, slowly diminishing its workforce and closing down its last blast furnace in $1998 .{ }^{6}$ Only the mechanical and the constructional engineering part of the Ironworks survived in its privatized form, which is now called the Vitkovice Holding Group.

Unlike the Hunedoara Ironworks, the Vitkovice Ironworks has been much more successful, at least since its privatization in 2003, to build a professional image and reinvent itself. Although the downsizing has been radical as well, with only about 5,138 employees currently working at the plant, ${ }^{7}$ the image of destruction is much less prevalent. More important, because of the early interest by a local government employee-Mr. Milos Matej, a conservator at the Heritage Council of Ostrava - to preserve the closed down parts of the Ironworks, they have now been assigned a UNESCO Industrial Patrimony Status ${ }^{8}$ and have received significant financial support to help with the preservation efforts from the European Route of Industrial Heritage Program. This has become one of the most substantial industrial preservation projects of its kind in Europe, comparable with Volklingen or Duisburg-Meiderich.

The gaze of the Vitkovice worker is thus one of longing, but perhaps also one of pride, as access to the once closed down sites has now been restored along with the museumization process, allowing them and their families to easily explore and relive the past through the preserved spaces. In a survey conducted by Charles University, $83 \%$ of the respondents, all Ostrava residents, "wanted to see the city remembered as a symbol of industry, while $91 \%$ believed that Vitkovice Ironworks is part of Ostrava's image" (Logan, 2003). Former miners saw the preservation efforts as paying homage to their work and their colleagues who died there and reiterated the importance of the local emotional connection to the site itself by calling the buildings "part of the landscape, region and history of Ostrava:" (Logan, 2003). Stopping the physical erasure of the Ironworks has thus had a significant impact on the local community, not only by reinforcing a sense of pride but also by creating the possibility of an endearing gaze, one that peruses the preserved sites from the inside and one that continues to explore them as an intrinsic part of the community. The umbillicum is preserved and what lies around it can once again thrive.

The preservation efforts have however only managed to capture a small part of a larger transformation, a small perspective from the thousands of gazes of workers who continue to work, often in dilapidated, half-dead environments, across a number of different industrial platforms throughout the Czech Republic. The Czech photographer Vaclav Jirasek ${ }^{9}$ has tried to capture some of these gazes through a series of striking portraits of workers as well as a number of exhibits featuring both abandoned as well as half-dead industrial sites across the Czech Republic. In his images, the Czech workers appear equally "destroyed" and abandoned as the workers of the rest of 
postcommunist Europe. Unlike the photographers of the Kombinat photo album in Romania, Jirasek chooses to draw a direct connection between the industrial space and "ruin" and the worker, showcasing in one of his latest exhibits - Industria - a series of striking portraits that seek "to depict the forgotten people, those tested by harsh reality."10

Just like the spaces themselves, the workers come across as ruined yet enduring elements, hurt yet strong, forgotten yet still present. The few that are left are presented as relics of an industrial world not so far removed, yet almost completely forgotten and erased from our modern consciousness. In Jirasek's photographs, the workers themselves seem to become part of the industrial patrimony, blending in with the factory space, enriching the color palette, and blurring the line between still "nature" and human portrait. The photographs focus not only on the workers and the spaces that they inhabit but also on material attempts to "tame" the otherwise inhospitable working environment through what Jirasek calls "strange home-made or individually adapted pieces of furniture and bizarre decorative 'installations.'.

When describing his fascination with industrial ruins, Jirasek writes the following:

Frequently, I had the sense that factories are live organisms, functioning outside the awareness of the individuals that work there. Old buildings interweave themselves with new ones; disused pipes and wires are left where they lie, with new ones sprouting on top of them like the lianas of the jungle. Industry's penetration of the landscape, and the following return of nature into industry's remnants, makes it clear that technology is only a peculiar form of nature itself. ${ }^{11}$

The question that remains is whether attempts to aestheticize technology, industrial spaces, and the workers inhabiting them should be analyzed along similar lines with now well-established attempts to aestheticize nature and landscape. If the human element implicated through the worker significantly different and if not, can the worker be easily associated with the previous image of the farmer, which, just like the worker, has been slowly removed from the current environmental and landscape aesthetics. The survival, at least partial, of some of these industrial plants also makes the question more difficult, to the extent that aesthetization practices are somewhat limited by access to the sites themselves (even when abandoned), as well as by lack of funding to follow the more costly path of museumization.

The importance of supporting anesthetization practices such as photography and film making or museumization lies in the fact that it is mainly through such practices that the link between industrial spaces - such as the largely abandoned industrial platforms of postcommunist Europeand their human inhabitants is clearly drawn. The focus on privatization and regional development policies often ignores the extent to which the identity of the space itself as well as its inhabitants are reliant on these industrial platforms, thus making decisions such as scraping entire parts of the "industrial patrimony" with ease and justifying them in terms of efficiency and profit making. This act of erasure is both dangerous and harmful.

\section{Conclusion}

Although a discussion of the failed privatization processes that have left many industrial sites within postcommunist Europe ruined would have been interesting in itself, and many perhaps would argue a much more acceptable and useful approach to the study of postcommunist transitions, the question of aesthetics needs to be brought to the fore as a number of different studies underline the essential role that different forms of sensory experiences play in the process of self-reflection and change. Any period of transition is marked not only by changes driven by processes such as privatization and institutional or economic reform but also, more important, by how people visualize 
the transition both in its concrete physical consequences - such as the ruin of their previous employment spaces - as well as in a series of different visions that single out specific elements of changethe odd pleasing aesthetics of scattered materials and textures that once formed an industry, the striking colors of polluted water and ground, the eagerness of former workers to find themselves useful again, or the return to an idyllic nature made possible by the collapse of industry.

This article has attempted to provide a series of perspectives through which the aesthetics of change could be analyzed: the connection between space and certain notions of utopia and dystopia that are used to create social and political collectivities, the relationship between space and body as mediated by the visual and so-called thought-images, as well as a number of different aestheticizing practices such as the naked gaze, photography, and museumization, which seek to realign the spatial and the temporal along different positionings between the object and the subject. Although the space of this article has only allowed for a relatively superficial exploration of each, it has hopefully managed to put the human suffering related to the material decay of former industrial platforms into a new field of vision, one that is less mediated by concerns over efficiency and economic development and more by an element of empathy and recognition of emotional attachments.

The positive depiction of a number of different aesthetic practices in the context of Hunedoara as well as Vitkovice is certainly open to a series of different challenges. The author's optimism toward such practices has mainly been justified in terms of their ability to shift our gaze - as workers, members of the local community, photographers, or an outside audience - toward new ways in which these spaces could retain their emotional and historical charge and continue to provide a sense of purpose as the umbillicum of these communities. Just like the ruination of these spaces has been directly connected to the ruination of the humans inhabiting them, there is a certain hope that the preservation, restoration, or even capturing of these spaces in a positive light would revive an essential sense of pride and, more important, provide a visible recognition that the lives who inhabit these spaces cannot and will not be simply erased along with the ruins themselves.

The ruins and the humans inhabiting them are live testimonies of a series of understated elements of all transitions: the destruction that precedes and often accompanies new constructions, the struggle to remain visible at a time when your trait, your skills, your job, your house, your city, and your very being is no longer viable, and the possibility of maintaining a sense of pride even after being made redundant, shamed, and humiliated. This is neither a call for nostalgia nor a visual support for a past that is no longer viable: it is simply a bow, a gesture that recognizes that something and someone is still there, among the ruins, attached to them from the inside and not simply experiencing them from the outside.

\section{Acknowledgments}

I would like to thank Thomas Diez, Matt Davies, the participants to the Osaka conference on Human Security that took place in March 2008, as well as my three anonymous reviewers for their insightful comments and suggestions.

\section{Declaration of Conflicting Interests}

The author(s) declared no potential conflicts of interest with respect to the authorship and/or publication of this article.

\section{Funding}

The author(s) received no financial support for the research and/or authorship of this article.

\section{Notes}

1. See, for example, the work of Vaclav Jirasek, the "7Days" Photography group in Romania, Nicki Lee Carlson, or Angus Boulton.

2. For a better explanation of this notion, see Pusca (2008). 
3. For more information, see the official Web site at http://cetateadefoc.lx.ro/ and http://www.arcelormittal .com.

4. Places such as Birmingham are living testimony: see the Custard Factory, the Ikon Gallery, and the National Trust museum sites.

5. For more information, see http://en.erih.net/index.php?pageId=109\&anchor=274\&cfilter=.

6. For a short history of the plant, see http://www.vitkovice.cz/10/en/node/214

7. See details in their 2006 annual report: http://www.vitkovicesteel.com/wysiwyg/file/vyrocni_zpravy/ EG-AR-2006.pdf

8. Much of the disused plant, the Hlubina Colliery, the coke ovens, and blast furnaces along Mistecka Street and the steel plant and rolling mill on Ruska Street, including many 19th-century buildings, have been declared a National Cultural Monument, and are in process of conservation. For more information, see http://en.erih.net/index.php?pageId=109\&anchor=274\&cfilter=.

9. For more information on his work, see http://www.vjirasek.com/index1.htm.

10. For more information, see http://www.moravska-galerie.cz/en/exhibitions/vaclav-jirasek/.

11. Quoted on the Web site of the Moravska Galerie: http://www.moravska-galerie.cz/en/exhibitions/ vaclav-jirasek.

\section{References}

Andresoiu B, (2006) Kombinat. Ruine industriale ale epocii de aur. (Kombinat: Industrial Ruins of the Golden Age). Bucharest: Igloo Media Press.

Barb, I. (2007). Hunedoara: decadenta unui imperiu de metal [Hunedoara: decay of a metal empire]. Retrieved from http://www.capital.ro/index .php?section=articole\&screen=index\&id=3425

Benjamin, W. (1970). A small history of photography (E. Jephcott \& K. Shorter, Trans.). In W. Benjamin (Ed.), One-way street. Frankfurt, Germany: Suhrkamp Verlag. Chapter pages: 240-257.

Benjamin, W. (1982). The Arcades Project (H. Eiland \& K. McLaughlin, Trans.). Cambridge, MA: Belknap Press of Harvard University Press.

Benjamin, W. (1998). The origin of German tragic drama. London, England: Verso. (Original work published 1963)

Bimbirica, O. (2007, June). Interviu: Imi vine sa plang cand vad combinatul. [Interview: I feel like crying when I see the industrial platform] Retrieved from http://www.replicahd.ro/replica_db/index.php?pagerun=2\&title=imi vine_sa_plang_cand_vad_combinatul\&more $=1 \& \mathrm{c}=1 \& \mathrm{tb}=1 \& \mathrm{pb}=1$. Replica Issue 240, 14-20 June 2007.

Bleiker, R. (2001). The aesthetic turn in international political theory. Millennium: Journal of International Studies, 30, 509-533.

Bleiker, R. (2007). Representing HIV/AIDS in Africa: Pluralist photography and local empowerment. International Studies Quarterly, 51, 139-163.

Boyer, C. (1988). The city of collective memory: Its historical imagery and architectural entertainments. Cambridge: MIT Press.

Boym, S. (2001). The future of nostalgia. New York, NY: Basic Books.

Buck-Morss, S. (1995, Summer). The city as dreamworld and catastrophe. October, 73, 3-26.

Buck-Morss, S. (2000). Dreamworld and catastrophe: The passing of mass utopia in east and west. Cambridge: MIT Press.

Cooke, M. (2002). Beirut reborn: The political aesthetics of auto-destruction. Yale Journal of Criticism, $15,393-424$.

Dahrendorf, R. (1997). After 1989: Morals, revolution and civil society. New York, NY: St. Martin's Press.

Der Derian, J. (2001). Virtous war: Mapping the military-industrial-media-entertainment network. Oxford, England: Westview Press.

Edensor, T. (2005a). The ghosts of industrial ruins: Ordering and disordering memory in excessive space. Environment and Planning, D: Society and Space, 23, 829-849.

Edensor, T. (2005b). Industrial ruins: Space, aesthetics, and materiality. Oxford, England: Berg. 
Foucault, M. (1967). Of other spaces, heterotopias. Retrieved from http://foucault.info/documents/heteroTopia/ foucault.heteroTopia.en.html

Gilloch, G. (1997). Myth and metropolis: Walter Benjamin and the city. London, England: Polity.

Graham, S. (2003, January). Lessons in urbicide. New Left Review, 19, 63-77.

Havel, V. (1992). Summer meditations. New York, NY: Alfred A. Knoff.

Hayden, D. (1997). The power of place: Urban landspaces as public history. Cambridge: MIT Press.

Heller, A. (1970). Everyday life (G. L. Campbell, Trans.). London, England: Routledge.

Iancu, B. (2006, April 27). Marirea si decaderea patrimoniului industrial Romanesc [The rise and decay of Romanian industrial patrimony]. Retrieved from http://www.bloombiz.ro/economie/ marirea-si-decaderea-patrimoniului-industrial-romanesc.

Iancu, C. (2007, June 7-13). Hunedoara, te-am pupat si am plecat! [Kisses and Good-bye Hunedoara!]. Replica. Retrieved from http://www.replicahd.ro/replica_db/index.php?pagerun=2\&p=118\&more $=1 \&$ $\mathrm{c}=1 \& \mathrm{tb}=1 \& \mathrm{pb}=1$

Iancu, S. (2007, May 28). Ruine Industriale ale Epocii de Aur. [Industrial Ruins of the Golden Age] Romania Libera. Retrieved from http://www.romanialibera.ro/actualitate/fapt-divers/ruine-industriale-ale-epociide-aur-96496.html

Iatridis, D., \& Gary Hopps, J. (1998). Privatization in central and eastern Europe: Perspectives and approaches. New York, NY: Praeger.

Ioan, A. (2006). Urban policies and the politics of public space in Bucharest. In S. Tsenkova \& NedovicBudic-Zorica (Eds.), The urban mosaic of post-socialist Europe (pp. 337-348). Heidelberg, Germany: Physica-Verlag.

Jaguaribe, B. (2005). The shock of the real: Realist aesthetics in the media and the urban experience. Space and Culture, 8, 66-82.

Kaldor, M., \& Vejvoda, I. (Eds.). (1999). Democratization in central and eastern Europe. London, England: Pinter.

Kirk, J. (2003). Mapping the remains of the postindustrial landscape. Space and Culture, 6, 178-186.

Kombinat: Industrial Ruins of the Golden Era. (2007). Bucharest, Romania: Igloo Press.

Lahusen, T. (2006). Decay or endurance? The ruins of socialism. Slavic Review, 65, 736-746.

Logan, S. (2003, March 19). Machines as monuments: Old industrial plant commemorates a lost way of life in Ostrava. The Prague Post. Retrieved from http://www.praguepost.com/archivescontent/36961machines-as-monuments.html

Luxenberg, A. (1998). Creating Desastres: Andrieu's photographs of urban ruins in the Paris of 1871. Art Bulletin, 80, 113-137.

Moore, C. (2006). Reading the hermeneutics of violence: The literary turn and Chechnya. Global Society, 20, 179-198.

Pusca, A. (2008). Revolution, democratic transition and disillusionment. Manchester, England: Manchester University Press.

Ranciere, J. (1989). The nights of labor: The worker's dream in 19th Century France. Philadelphia, PA: Temple University Press. (Original work published 1981)

Ranciere, J. (2005). From politics to aesthetics? Paragraph, 28(1), 13-25.

Roy, J.-M., \& Goulard, L. (1986). Les Forges du Saint-Maurice blast furnace complex. Bulletin of the Association for Preservation Technology, 18(1/2), 32-37.

Schonle, A. (2006). Ruins and history: Observations on Russian approaches to destruction and decay [Hunedoara: from communism to capitalism]. Slavic Review, 65, 649-669.

Sennett, R. (1994). Flesh and stone: The body and the city in Western civilization. New York, NY: W. W. Norton.

Shapiro, M. (2006). The sublime today: Re-partitioning the global sensible. Millennium: Journal of International Studies, 34, 657-681.

Simmel, G. (1959). The ruin. In K. Wolff(Ed.), Georg Simmel 1858-1918. Columbus: Ohio State University Press. 
Somerii inregistrati si rata somajului [The unemployed and unemployment rate]. (n.d.). Retrieved from http:// www.hunedoara.insse.ro/main .php?lang=fr\&pageid $=481$

Staff, W. (2004, January 28). Companiile transnationale supun guvernele si popoarele: Maharajul otelului LN Mittal joaca pe degete economia a 12 tari [Transnational companies conquer governments and people: Steel Maharaja LN Mittal has the economies of 12 countries at his fingertips]. Evenimentul Retrieved from http://www.evenimentul.ro/articol/maharajahul-otelului-ln-mittal.html.

Staff, W. (2007a, May 10). Hunedoara, de la comunism la capitalism [Hunedoara: from communism to capitalism]. Replica.

Staff, W. (2007b). Romania's Mittal Steel Roman H1 net profit falls 7.8\%. Retrieved from http://www.seenews .com/news/latestnews/romania_smittalsteelromanh1netprofitdown7_8_y_y-101707/

Thirkell, J. E. M., Petkov, K., \& Vickerstaff, S. (1998). The transformation of labour relations: Restructuring and privatization in Eastern Europe and Russia. Oxford, England: Oxford University Press.

Tismaneanu, V. (1991). Condamnati la Fericire: Experimentul Comunist in Romania [Condemned to Happiness: The Communist Experiment in Romania]. Sibiu, Brasov: Fundatia Exo.

Tolle, A. (2008). City profile: Gdansk. Cities, 25(2), 107-119.

Vergara, C. J. (1996). American acropolis. New Statesman \& Society, 9(385), 16-20.

Weber, C. (2006). Imagining America at war: Morality, politics and film. London, England: Routledge.

World Health Organization. (2006). Suicide rates. Retrieved from http://www.who.int/mental_health/media/ romania.pdf

\section{Bio}

Anca Pusca is a lecturer in international studies in the Department of Politics at Goldsmiths, University of London. She is the author of several books, including Revolution, Democratic Transition and Disillusionment: The Case of Romania (2008), and she works on questions related to aesthetics and politics. 